Bartın Üniversitesi

Eğitim Fakültesi Dergisi

Cilt 6, Sayı 2, s.657-675, Haziran 2017 BARTIN - TÜRKIYE

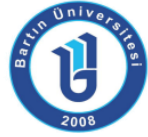

ISSN: 1308-7177
Bartin University

Journal of Faculty of Education

Volume 6, Issue2, p. 657-675, June2017

BARTIN - TURKEY

\title{
Yedinci Sınıf Öğrencilerinin Cebirsel Düşünme Düzeyleri İle Becerilerinin İncelenmesi
}

Deniz KAYA, Dr., Milli Eğitim Bakanlığı, denizkaya38@gmail.com

Öz: Bu araştırmada yedinci sınıf öğrencilerinin, (i) cinsiyete göre cebirsel düşünme düzeylerini, (ii) cebir öğrenme alanındaki pozitif ve negatif beceri eksikliklerini incelemek amaçlanmıştır. Tarama modelinin benimsendiği çalışma, yedinci sınıf düzeyinde toplam 185 öğrenci ile yürütülmüştür. Veri toplama aracı olarak; literatürde yer alan çalışmalar, ortaokul matematik ders kitapları ile öğretim programında yer verilen ilgili kazanımlar göz önüne alınarak hazırlanan 10 soruluk "Cebirsel Düşünme Düzeyi Belirleme Aracı (CDDBA)" kullanılmıştır. Verilerin analizinde betimsel istatistiksel tekniklerinden yararlanılmıştır. Betimsel analiz sonuçlarına göre, öğrencilerin cebir öğrenme alanı ile ilgili doğru cevap oranlarının ilk aşamadan son aşamaya gidildikçe belirgin şekilde azaldığı belirlenmiştir. Öğrencilerin pozitif beceri eksiklikleri iki aşamada \%27, üç aşamada \%13 iken negatif beceri eksiklikleri iki aşamada $\% 49$, üç aşamada \%19 olarak bulunmuştur. Diğer yandan öğrencilerin cebirsel düşünme düzeylerinin genel ortalaması 15.09, her bir soruya göre erkek öğrencilerin ortalaması 1.32, kız öğrencilerin 1.70 olarak hesaplanmıştır. Öğrencilerin cebirde yaşadıkları güçlüklerin temel nedenlerini belirlemeye yönelik öğretim programı dâhilinde boylamsal çalışmalara ağırlık verilmesi öneri olarak sunulmuştur.

Anahtar Kelimeler: cebirsel düşünme, cinsiyet, negatif ve pozitif beceri, yedinci sınıf

\section{Examination the Skills and Levels of Seventh Grade Students on Algebraic Thinking}

\begin{abstract}
In this study, the purpose is to examine (i) the algebraic thinking levels of seventh grade students according to gender; and (ii) the positive and negative skill deficiency of them in learning algebra. The literature review method was used in the study, which was conducted with 185 students at seventh grade. The data collection tool, the studies in the literature were used, and the "Algebraic Thinking Level Determination Tool (ATLDT)", which was prepared by considering the acquisitions given in secondary school mathematics course books and in the curriculum. The scale consisted of 10 questions. The descriptive statistical techniques were made use of in the analysis of the data. According to the descriptive analysis results, it was determined that the true answer rates of the students on algebraic learning field decreased at an obvious manner from the first stage towards the last stage. The positive skill deficiencies of the students were at $27 \%$ in the second stage; $13 \%$ in the third stage; and negative skill deficiencies of them were at $49 \%$ in the second stage; and $19 \%$ in the third stage. On the other hand, the general average of the students in algebraic thinking level was 15.09; the average of male students according to each question was 1.32; and that of the female students was determined as 1.70. It was recommended in the study to conduct longitudinal studies within the curriculum intended to determine the basic reasons of the difficulties experienced in algebra by students.
\end{abstract}

Key Words: algebraic thinking, gender, negative and positive skill, seventh grade 


\section{GíRiş}

Cebir, matematik biliminin soyutluğunu resmeden ve yapısı itibarıyla soyut düşünmeye kapı aralayan öğrenme alanıdır. Bir çeşit aritmetiğin genelleştirilmiş hali olan cebir, sembolik gösterimler yardımıyla kökünü aldığı aritmetiğin gelişimine de öncülük eder (Bills, Wilson \& Ainley, 2005; Kieran \& Chalouh, 1993; Tabach \& Friedlander, 2003; Van Amerom, 2002). Çünkü cebir genel sayı ilişkilerini ve özelliklerini gösteren; bilinmeyenleri, formülleri, örüntüleri, yer tutucuları ve ilişkileri içeren matematiğin bir dili olarak kabul edilir (Akkan, 2009). Bu özelliğinden dolayı hem soyut düşünmeye hem de mantıksal çıkarım yapmaya kapı aralamakla kalmaz, diğer bilim dallarının öğeleri arasında kavramsal ve kuramsal çerçeve çizerek ortak bir köprü ve dil görevi üstlenir (Erbaş, Çetinkaya \& Ersoy, 2009; Stacey \& MacGregor, 1999). Matematik öğretmenlerinden oluşan ulusal konsey cebirin standartlarını; fonksiyonel ilişkileri simgeleyen gösterimler, değişimin çözümlenmesini sağlayan araçlar ve sembollerin dili olarak tanımlamaktadır (National Council of Teachers of Mathematics [NCTM], 2000). Bu bakımdan bir dil, bir problem çözme aracı, bir okul dersi, bir düşünce sistematiği ve bir zihin jimnastiği olarak yaşamın her anında cebirsel kavramlara sıkça rastlanılmaktadır (Dede \& Argün, 2003). Çok yönlü bu özelliğinden dolayı yalnızca matematikte değil edebiyat, fizik, sanat, ekonomi ve müzik gibi sürekli gelişen bir insan etkinliği olarak çok önemli bir konum edinmiştir (Akgün, 2006; Baki \& Bütüner, 2011). Cebir alanındaki bilgi ve becerilerin bu denli yoğun olması beraberinde cebirsel düşünmeye olan ihtiyacı da doğurmaktadır. Illgili literatür incelendiğinde, cebirsel düşünmenin tanımına yönelik çok sayıda görüşe rastlamak mümkündür. Driscoll ve diğer., (2001) cebirsel düşünmeyi değişkenler arasındaki ilişkileri ortaya çıkarmaya yardımcı niceliksel durumlar şeklinde yorumlamaktadır. Bir çeşit zihinsel aktivite olan cebirsel düşünme; sembollere anlamlar yükleyerek cebirsel ilişkiler arasında bağ kurmayı, cebirsel ilişkilerin içerisinde yer alan somut-yarı somut ve soyut kavramları betimlemeyi ve muhakeme etme yoluyla sonuca ulaşabilmeyi temsil eder (Kaya, 2015). Swafford ve Langrall (2000) cebirsel düşünmeyi bilinmeyen miktarları bilinen gibi düşünme, Kieran (1996) nicel durumları ilişkisel bir şekilde analiz etmek için çeşitli gösterimleri kullanma, NCTM (2000) gerçek yaşamla ilgili çeşitli durumlardaki değişimi analiz etme, Carpenter ve Levi (2000) matematiksel fikirleri temsil etmek ve problemleri çözmek için semboller kullanma, Lawrence ve Hennessy (2002) dünyayı daha iyi yorumlamaya ihtiyaç duyulan anlayış kümesi, Kieran ve Chalouh (1993) ise aritmetiksel bir dille cebirsel işlemlere ve sembollere anlam yükleme yeteneği olarak tanımlamaktadır. Genel anlamda ise kavramsal anlayış, işlemsel akıcılık, geometriksel akıl yürütme ile ilk ve ortaokulda tanıtılan ve öğretilen ölçüm kavramlarıyla ilişkili süreçler üzerine kurulmuş zihin alışkanlıkları bir başka ifade ile matematiksel içerik hakkında faydalı düşünceler denilebilir (Cuoco, Goldenberg \& Mark, 1996; Kaput, 2008).

Alanyazın irdelendiğinde, cebirsel düşünmenin gelişimi ve nasıl ortaya çıktığı konusunda değişik görüşlere rastlanılmaktadır. Cebirsel düşünmenin örüntü gibi aktivitelerle (Blanton \& Kaput, 2003), nümerik ve aritmetikle (Slavit, 1999), benzerlikleri ve farklılıkları tespit etmekle (Mason, 1996) ortaya çıktığı belirtilmektedir. Bir başka görüş ise öğrencilerin cebirsel düşüncelerinin üç aşamada gelişme ve ilerleme gösterdiği yönündedir. Buna göre, öncelikle öğrenciler genel dilde ilişkileri ve genellemeleri açıklar, daha sonra matematiksel semboller ve diyagramlar kullanarak oluşturdukları fikirleri kısaltır, son olarak bu fikirleri matematiksel ifadeler, denklemler, değerler tablosu ve grafikler kullanarak özetler (Mason, Graham \& Johnston-Wilder, 2005; NCTM, 2000). Bu görüşe, Driscoll ve Moyer (2001) cebirsel düşüncenin göstergesi olarak; (a) sistematik bir kural arama, (b) genelleştirilmiş bir kural oluşturma, (c) genelleştirilmiş bir kuralı tahmin etme, (d) bu kuralı başka formlarda temsil etme, (e) farklı gösterimlerle bağlantı kurma şeklinde beş aşamadan oluşan bir rehber oluşturarak farklı bir bakış açısı getirmiştir. Kaput’a (2008) göre cebirsel düşünmenin gelişimi; (i) genellemeler yapmak ve bu genellemeleri gittikçe artan geleneksel simge sistemlerinde 
ifade etmek, (ii) sembolik formlarla akıl yürütme şeklinde çekirdek iki ana temadan oluşmaktadır. Radford (2014) ise cebirsel düşünmeyi; belirsizlikler (bilinmeyenler, değişkenler, parametreler), ifadeler (belirsizliklerin işaretleri veya sembolleri) ve analitiklik (belirsiz miktarları bilinen sayılarmış gibi değerlendirme) şeklinde üç kategoride ifade etmiştir. Sonuç olarak, cebirsel düşünmenin temel olarak zihinsel bir alışkanlık (Driscoll, 1999), genel bir aktivite (Kieran, 1996) ile olayları açıklamak ve tahmin etmek için bilgi veya olayları matematik diline çevirerek dünyayı daha iyi yorumlamaya olan gereksinimlerin ortaya çıkardığı fikri ağırlık kazanmaktadır (Lawrence \& Hennessy, 2002).

Birçok araştırmacı cebirin öğrenciler için kritik bir konu olduğunu ve cebirsel düşüncenin erken yaşlarda geliştirilmesi gerektiğine vurgu yapmaktadır (Blanton \& Kaput, 2003; Cai, 2004; Carraher \& Schliemann, 2007; Kaput \& Blanton, 2001; Kieran, 1996; Moses, 1995; NCTM, 2000; Schliemann, Carraher \& Brizuela, 2007). Bu açıklamanın temel gerekçesi erken yaşlardaki cebirsel düşünme gelişiminin öğrencilerin cebirsel sembollerle olan temasını kolaylaştırması olarak gösterilmektedir (Cai \& Knuth, 2011). Dolaysıyla matematik konularında yer alan pek çok kavram, sembolleri anlamaksızın kolay bir şekilde öğrenilemez (Lew, 2004). Aksine düşüncelerin inşası için okullardaki cebirsel deneyim oldukça önemlidir (NCTM, 2006). Diğer yandan cebirsel kavramlar ileri seviye bir matematik anlayışının gelişmesinde ve içeriğinin anlaşılmasında son derece etkilidir. Özellikle matematiksel modeller olarak farklı olguların tasarlanmasında, organize edilmesinde, genelleme bilincinin gelişmesinde ve matematiksel alan uygulamalarında etkin görevler üstlenirler (Irwin \& Britt, 2005; NCTM, 2006; Peled \& Carraher, 2004; Shternberg \& Yerushalmy, 2003). Ancak hem soyut yapısından hem de kurallar öğrenmek gibi algılamasından dolayı öğrenenler tarafından nefret etmekten hoşlanılır hale gelmiştir (Kaput, 1999). Nitekim gerek ulusal gerekse uluslararası araştırma raporları öğrencilerin cebirsel düşünme performanslarının istenilen seviyenin oldukça gerisinde kaldığını ve cebirde zorlandıklarını göstermektedir (Kaput \& Blanton, 2001; Dede \& Argün, 2003; Ersoy \& Erbaş, 2005; Kaya, 2015; NCTM, 2000; OECD, 2016; TIMSS, 2016). Örneğin, Uluslararası Eğitim Başarılarını Değerlendirme Kuruluşu tarafından yayınlanan 2015 raporuna göre; sekizinci sınıf düzeyindeki matematik sorularının \%30'unu [61 madde] oluşturan cebir sorularında, alt ölçek puanı genel matematik notuna göre oldukça düşük olan aralarında Kanada, İrlanda, Ingiltere, İtalya, Slovenya ve Norveç'in de bulunduğu 14 ülke yer almaktadır. Ayrıca katılımcı 39 ülkenin cebir performansı dikkate alındığında aralarında Türkiye, Norveç, Yeni Zelanda, Malezya, İtalya ve Şili'nin yer aldığı 24 ülkenin cebir performansı ortalamanın [37 puan] gerisinde kalmıştır (TIMSS, 2016). Bu sonuç, birçok faktör grubunun ortak paydasını oluştursa da literatürde sıkça dile getirilen öğrencilerin cebirde zorlandıkları söylemleri ile örtüşmektedir (Akgün, 2007; Bağdat \& Anapa-Saban, 2014; Dede \& Argün, 2003; Ersoy \& Erbaş, 2005; Kaya ve diğer., 2016; Yenilmez \& Avcu, 2009; Özarslan, 2010; Soylu, 2008; Van Amerom, 2003).

İlgili alanyazın incelendiğinde, Yenilmez ve Avcu (2009) tarafından yürütülen çalışma sonucunda, öğrencilerin eşitliğin gösterimi ve korunumu sorularında genellikle problem yaşamadığı ancak denklem kurma ve kurulan denklemi çözme problemlerinde zorluk çektikleri belirlenmiş̧ir. Rosnick (1981) tarafından yürütülen çalışmada, "Bir üniversitedeki öğrenciler profesörlerin 6 katıdır. Öğrenciler için S, profesörler için P'yi kullanarak denklemi ifade ediniz?" sorusu yöneltmiş ve öğrencilerin yalnızca \%37'si $S=6 P$ şeklinde veya başka bir formda denklemi doğru yazabildikleri rapor edilmiştir. Benzer şekilde, Ersoy ve Erbaş (2005) tarafından bir grup Türk öğrencinin cebir başarılarının araştırıldığı çalışmada eşitlikler ve problemler içeren soru kümelerinde öğrencilerin başarı düzeylerinin düştüğü ve çok sayıda yanlış yaptıkları belirlenmiştir. Özarslan (2010) tarafından 364 yedinci sınıf öğrencisi ile yürütülen çalışma sonucunda ise öğrencilerin cebirsel sözel problemlere denklem kurma ve kurdukları denklemi çözme başarılarının düşük olduğu ayrıca problem durumuna uygun denklem kurarken ve kurulan denklemi çözerken bazı hata türlerine sahip oldukları ifade edilmiştir. Akgün (2007) 
tarafından sekizinci sınıf düzeyinde 158 öğrenci ile yürütülen çalışma sonucunda, öğrencilerin değişken kavramını anlamada, değişken kavramı veya harfli ifadelerle işlem yapmada, değişkenle kelime problemleri arasında ilişki kurmada ve bu kavramın farklı kullanımlarını ayırt etmede bir takım zorluklara ve kavram yanılgılarına sahip oldukları görülmüştür. Van Amerom (2003) yaşları 10 ile 13 arasında değişen altıncı ve yedinci sınıf öğrencileriyle yürüttüğü çalışmada ise sözel problemlere uygun denklem oluşturmada, yorumlamada, yapılandırmada, hesaplamada ve cebirsel ifadeleri basitleştirmede öğrencilerin zorlandıklarını rapor etmiştir. Erbaş, Çetinkaya ve Ersoy (2009) tarafından 217 öğrenci ile yürütülen çalışma sonucunda, düşük başarı seviyesindeki öğrenci yanlışlarının, daha çok yanlış kurallamalar odaklı, orta ve yüksek başarı seviyesindekilerin ise daha çok aritmetik veya işlemsel olduğu gözlemlenmiştir. Soylu (2008) tarafından 50 yedinci sınıf öğrencisi ile yürütülen başka bir çalışma sonucunda, bazı öğrencilerin sözel problemlerde verilen dört işlemle ilgili daha, eksik, fazla kavramlarını anlamlandırmada sıkıntı yaşadıkları belirlenmiştir. Örneğin öğrencilerin $h+10$ cevabını vermesi gerekirken 10h, $y-1$ cevabını vermesi gerekirken $y+1$ gibi cevaplar verildiğine rastlanılmıştır. Kaya ve diğer., (2016) tarafından 146 yedinci sınıf öğrencisi ile yürütülen çalışmada ise öğrencilerin cebirsel yapıları/ilişkileri tanıma, aynı verinin farklı cebirsel ifadelerini kullanma, uygun cebirsel muhakemeyi belirleme, cebirsel ifadelere yönelik çıkarımda bulunma, çıkarıma yönelik cebirsel işlemler yapma, sonucun doğruluğuna ve çözüm yoluna karar verme ile rutin olmayan problemleri çözme becerilerine ait test puanlarının düşük veya orta düzeyde olduğu rapor edilmiştir.

Alanyazında yürütülen çalışmalar genel olarak değerlendirildiğinde, cebir öğretiminin önemi dile getirilmekle birlikte öğretimi konusunda zorlukların yaşandığı vurgulanmaktadır. Hiç şüphesiz sadece matematik dersi değil birçok disiplin için cebire duyulan ihtiyaç kaçınılmazdır. Cebirin bu çok yönlü özelliği ve çok farklı işlevlerde kritik roller üstlenmesi öğrencilerin cebirsel düşünme becerilerini en doğru ve en verimli şekilde kullanmaları gerektiğine ortam hazırlamaktadır. Nitekim cebir önemlidir dolaysıyla öğrenciler yaşamlarında ve matematikte başarılı olabilmek için cebirsel düşünme becerilerini en iyi şekilde kullanmaları gerekir (Cai, 2004; Driscoll \& Moyer, 2001; Ersoy \& Erbaş, 2005; Kaput \& Blanton, 2001; Kaput, 2008; Kaya, 2015; NCTM, 2000). Bu bağlamda, özellikle gelişim ve değişimin hızlı bir şekilde yaşandığı günümüz toplumlarında öğrencilerin cebirsel düşünmelerindeki seviyenin takibi önemlidir. Bu bakımdan hem ulusal hem de uluslararası kuruluşlar ve araştırmalara kaynak oluşturması açısından öğrencilerin cebirsel düşünme düzeylerinin incelenmesi araştırmaya değer bir konu olarak karşımıza çıkmaktadır. Çünkü eğitim ve öğretim faaliyetlerindeki niteliğin artmasına bağıı olarak öğrencilerin cebirsel düşünme becerilerindeki değişimin yıllar içindeki farklıığının ortaya konması önem arz etmektedir. Özellikle cebir konularının yoğun bir şekilde ele alındığı ve soyut düşünme yapısının hızlı bir gelişim gösterdiği yedinci sınıf düzeyinin incelenmesi de ayrı bir değer taşımaktadır. Yürütülen çalışmanın en önemli gerekçelerinden birisi de alanyazında yer alan çalışmaların tek bir soru sistematiğine dayalı olarak öğrencilerin cebirsel düşünmelerini incelemesidir. Dolaysıyla yürütülen çalışmanın en güçlü yönü çoktan seçmeli test, açık uçlu soru ve çözüme yönelik görüşlere yer vererek daha ayrıntılı bir analize imkân tanımasıdır. Örneğin öğrencinin verdiği cevap için ilk aşama doğru, ikinci aşama yanlış ancak üçüncü aşamada emin veya oldukça eminse "pozitif beceri eksikliği", ilk aşama yanlış, ikinci aşama doğru, son aşamada emin veya oldukça eminse "negatif beceri eksikliği" olarak değerlendirilmiştir. Bu yönüyle cebir öğrenme alanı ile ilgili soruların her bir aşamasına farklı bir görev tanımı yüklenerek daha ayrıntılı veri seti elde edilmeye çalışılmıştır. Tüm anlatılanlar ışığında, yürütülen çalışma kapsamında yedinci sınıf öğrencilerinin; (i) cinsiyete göre cebirsel düşünme düzeyleri, (ii) cebir öğrenme alanındaki pozitif ve negatif beceri eksiklikleri üç aşamada incelenerek alanyazında yer alan farklı ve çelişkili bulguların anlaşıımasına katkı sağlamak amaçlanmıştır. 


\section{YÖNTEM}

\subsection{Araştırma Modeli}

Araştırmada yedinci sınıf öğrencilerinin cebirsel düşünme düzeyleri ile cebir öğrenme alanındaki pozitif/negatif becerileri incelendiğinden tarama modeli benimsenmiştir. Çalışmada belirli bir grubun cebirsel düşünme düzeyi ile becerisi var olduğu şekliyle betimlenmeye çalışılmıştır. Nitekim tarama modelleri, çok sayıda elemandan oluşan bir evrende, evren hakkında genel bir yargıya varmak amacı ile evrenin tümü ya da ondan alınacak bir grup üzerinde yapılan düzenlemeler olarak kabul edilir (Karasar, 2013).

\section{2. Çalışma Grubu}

Araştırmanın çalışma grubunu, 2016-2017 eğitim-öğretim yılında İzmir ili merkezindeki bir devlet ortaokulunun yedinci sınıfında öğrenim gören 93'ü kız (\%50.3) ve 92'si erkek (\%49.7) olmak üzere rastgele seçilen toplam 185 öğrenci oluşturmaktadır.

\subsection{Veri Toplama Aracı}

Veri toplama aracı olarak; literatürde yer alan çalışmalar, ortaokul matematik ders kitapları ile öğretim programında yer alan ilgili kazanımlar göz önüne alınarak hazırlanan 10 soruluk "Cebirsel Düşünme Düzeyi Belirleme Aracı (CDDBA)" kullanıımıştır. Hazırlanan soruların ölçme amacına uygun olup olmadığını ve ölçülmek istenen alanı temsil edip etmediğini belirlemek için uzman görüşü alınır (Karasar, 2013). Bu amaç doğrultusunda, hazırlanan sorular üç matematik eğitimcisine ve beş matematik öğretmenine gösterilerek önerileri doğrultusunda gerekli düzenlemeler yapılmıştır. Örneğin; bir problem durumuna ait soru cümlesinin çözümü iki bilinmeyenli bir denklem içerdiği için yeniden düzenlenmiştir. Bu aşamadan sonra uygulama öğrencileri dışındaki 33 kişilik bir öğrenci grubu ile pilot çalışma yapılarak öğrencilerin anlamakta güçlük çektiği noktalar tespit edilmiş ve gerekli düzeltmeler yapılmıştır. Örneğin; bir problem durumuna ait soru cümlesi öğrenciler tarafından farklı anlaşılmaya neden olduğu için yeniden düzenlenmiş başka bir soru cümlesi ise öğrencilere oldukça zor geldiği için ölçme aracından çıkartılmıştır. Bu sayede hazırlanan sorulara ait dil, seviye, uygunluk ve içerik geçerliliği sağlanmıştır. Ölçme aracındaki her bir soru üç aşamada değerlendirilmiştir. Illk aşama çeldiricilerle birlikte doğru yanıtın yer aldığı çoktan seçmeli dört seçenekten oluşmaktadır. İkinci aşama ilk aşamada işaretlenen seçeneğe ilişkin çözümün yapıldığı kısımdır. Üçüncü aşama ise ikinci aşamada verilen yanıta "Emin Değilim", "Kararsızım", "Eminim" ve "Oldukça Eminim" ifadelerden birisinin işaretlendiği kısımdır. 10 soruluk ölçme aracın Cronbach alpha güvenirlik katsayısı $.89(N=185)$ olarak hesaplanmıştır. Bunun yanı sıra CDDBA'ya ait veri setinin $\% 27$ 'lik alt ve üst grup ilk aşama madde güçlüğü .42-.73, ayırt ediciliği .46-.80; ilk iki aşama için madde güçlüğü .30-.45, ayırt ediciliği .38-.86 ve üç aşama için madde güçlüğü .20-.43 ve ayırt ediciliği .38-.86 aralıklarında yer almaktadır. Bir test maddesinin güçlük indeksinin $.20-.80$ aralığında, ayırt edicilik indeksinin .30'dan yüksek olması önerilmektedir (Tekin, 2016). Buna göre, ölçme aracında hem madde güçlük indeksi hem de madde ayırt edicilik indeksi açısından sorunlu bir madde bulunmamaktadır. 10 soruluk nihai ölçme aracının ortalama güçlüğü .30 ve ortalama ayırt ediciliği ise .59 olarak belirlenmiştir. Ölçme aracının ölçüm güvenilirliği ilk aşama, ilk iki aşama ve üç aşama için sırasıyla .69, .92 ve .90 olarak hesaplanmıştır. Diğer yandan ölçme aracında bulunması gereken bazı varsayımların karşılanmasına da dikkat edilmiştir. Öncelikle ilk iki aşama puanı ile üçüncü aşamada toplam kendine güven puanları arasındaki ilişki Pearson momentler çarpımı korelasyon katsayısı ile araştırılmıştır. İki aşama puanı ile kendine güven puanı arasında pozitif ve anlamlı $(r=.45, p<0.001)$ bir ilişki olduğu, iki aşama puanı yüksek olanların güven puanının da yüksek olduğu belirlenmiştir. Son olarak, bazı öğrencilerin düşük puan almasına rağmen verdiği cevaplarda kendinden oldukça emin olması korelasyon katsayısı değerini düşürdüğünden şans eseri soruyu doğru cevaplayanlarda dikkate 
alınmıştır (Peşman \& Eryılmaz, 2010). Bu amaçla, Point-Biserial korelasyon katsayısı yani test maddesine verilen doğru cevaplar ile toplam alınan puan arasındaki ilişki belirlenmiştir. Elde edilen değer -1 ile +1 arasında değişmekte ve .20 'den büyük değerler kabul edilebilmektedir. Ne kadar yüksek değer elde edilirse test maddesi, düşük puan alan öğrenciler ile yüksek puan alan öğrencilerin ayrımını o kadar iyi yapmaktadır (Wuttiprom ve diğer., 2009). Ölçme aracında yer alan her bir sorunun aşama üç puanı ile toplam puan arasındaki korelasyon katsayısı .54 olarak hesaplanmış ve tüm maddelerin .20'den büyük ve kabul edilebilir [0.40-0.49 arasında 2 , 0.50-0.59 arasında 7, 0.60-0.69 arasında 1 madde] değerler aldığı belirlenmiştir. Bu bağlamda, kazanıma uygun olarak hazırlanmış örnek soru cümlesi ve ait olduğu kazanım aşağıdaki tabloda sunulmuştur.

Tablo 1

Örnek Soru ve Kazanım

\begin{tabular}{|c|c|c|}
\hline Aşama & Örnek Soru ve İşlem Adımları & Kazanım \\
\hline \multirow[t]{2}{*}{1} & $\begin{array}{l}\text { Melike, her gün bir önceki gün okuduğu sayfa sayısının } 3 \text { katı kadar sayfa } \\
\text { okuyarak kitabını } 3 \text { günde bitiriyor. Kitap toplam } 130 \text { sayfa olduğuna göre, } \\
\text { Melike'nin ilk gün kaç sayfa kitap okuduğunu veren denklem aşağıdakilerden } \\
\text { hangisi olabilir? }\end{array}$ & \multirow{5}{*}{$\begin{array}{l}\text { Birinci } \\
\text { dereceden } \\
\text { bir } \\
\text { bilinmeyenli } \\
\text { denklem } \\
\text { kurmayı } \\
\text { gerektiren } \\
\text { problemleri } \\
\text { çözer }\end{array}$} \\
\hline & $\begin{array}{llll}\text { A) } k+k+k=130 & \text { B) } 3 \cdot(k+k+k)=130 & \text { C) } k+(3 \cdot k)+(9 \cdot k)=130 & \text { D) } k \cdot(3 \cdot k) \cdot(9 \cdot k)=130\end{array}$ & \\
\hline 2 & $\begin{array}{l}\text { Melike'nin ilk gün kaç sayfa kitap okuduğunu işlem yaparak bulunuz. } \\
\text { Çözüm: }\end{array}$ & \\
\hline \multirow[b]{2}{*}{3} & Illk iki soruya verdiğiniz yanıtlardan ne kadar eminsiniz? & \\
\hline & 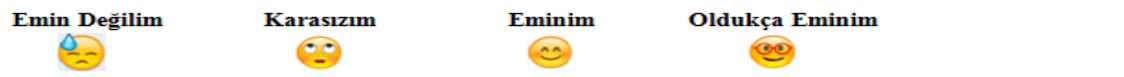 & \\
\hline
\end{tabular}

\subsection{Verilerin Analizi}

Verilerin analizinde betimsel istatistiksel tekniklerinden yararlanılmıştır. Veri setinin analiz edilmesinde SPSS 22.0 paket programı kullanılmıştır. Çoktan seçmeli soruların yer aldığı ilk aşama doğru ise " 1 " yanlış ise " 0 " olarak kodlanmıştır. İkinci aşamada Marzano'un (2000) aşamalı puan ölçeğinden yararlanılmıştır. Buna göre; (i) öğrenci en etkili çözüm yolunu seçer ve tam olarak açıklarsa 4, (ii) en etkili çözüm yolunu seçer ve tam olarak açıklayamazsa 3, (iii) doğru bir çözüm yolu seçer ama verdiği cevap çözüm sürecini kısmen açıklarsa 2, (iv) seçmiş olduğu çözüm yolu engelin veya zorluğun üstesinden gelebilecek nitelikte değilse 1 , (v) hiçbir yargıda bulunmazsa 0 olarak kodlanmıştır. Üçüncü aşamada ise "Eminim" ya da "Oldukça Eminim" ifadeleri için "1" "Kararsızım" ya da "Emin Değilim" ifadeleri için "O" kodlanmıştır. Son olarak, Arslan, Çiğdemoğlu ve Moseley (2012) tarafından kavramsal anlamaların ele alındığı kriterlere göre değerlendirme yapılmıştır (bkz. Tablo 2). Eğer öğrencinin verdiği cevap için ilk iki aşama doğru ve emin veya oldukça eminse "ileri Cebir Seviyesi" olarak kabul edilmiştir. Öğrencinin verdiği cevap için ilk aşama doğru, ikinci aşama yanlış ancak üçüncü aşamada emin veya oldukça eminse "Pozitif Beceri Eksikliği", ilk aşama yanlış, ikinci aşama doğru, son aşamada emin veya oldukça eminse "Negatif Beceri Eksikliği" olarak kabul edilmiştir. Eğer öğrencinin verdiği cevap ilk iki aşama için yanlış ancak son aşama için emin veya oldukça eminse "Düşük Cebir Seviyesi", ilk iki aşama doğru ancak son aşamada emin değil veya kararsız ise "Kendine Güven Eksikliği" olarak değerlendirilmiştir. Diğer yandan öğrencinin verdiği cevap için ilk aşama yanlış, ikinci aşama doğru, üçüncü aşama emin değil veya kararsız ise "Güvensiz Pozitif Beceri", ilk aşama doğru, ikinci aşama yanlış, üçüncü aşama emin değil veya kararsız ise "Güvensiz Negatif Beceri", ilk iki aşama yanlış, son aşamada emin değil veya kararsız ise "Cebir Öğrenme Güçü̆̈̈̈" olarak değerlendirilmiştir. 
Tablo 2

Ölçme Aracı Değerlendirme Ölçütleri

\begin{tabular}{|c|c|c|c|}
\hline ilk Aşama & ìkinci Aşama & Üçüncü Aşama & Kategoriler \\
\hline Doğru & Doğru $^{+}$ & Emin - Oldukça Emin & İleri Cebir Seviyesi ${ }^{\varphi}$ \\
\hline Doğru & Yanlış $^{\dagger}$ & Emin - Oldukça Emin & Pozitif Beceri Eksikliği* \\
\hline Yanlış & Doğru $^{\dagger}$ & Emin - Oldukça Emin & Negatif Beceri Eksikliği* \\
\hline Yanlış & Yanlış ${ }^{\dagger}$ & Emin - Oldukça Emin & Düşük Cebir Seviyesi» \\
\hline Doğru & Doğru $^{\dagger}$ & Emin Değil - Kararsız & Kendine Güven Eksikliği ${ }^{\bullet}$ \\
\hline Yanlış & Doğru $^{\dagger}$ & Emin Değil - Kararsız & Güvensiz Pozitif Beceri^ \\
\hline Doğru & Yanlış ${ }^{\dagger}$ & Emin Değil - Kararsız & Güvensiz Negatif Beceri^ \\
\hline Yanlış & Yanlış ${ }^{\dagger}$ & Emin Değil - Kararsız & Cebir Öğrenme Güçlüğü^ \\
\hline
\end{tabular}

\section{BULGULAR}

Bu bölümde, ölçme aracından elde edilen veriler doğrultusunda, öğrencilerin cebir öğrenme alanındaki doğru cevap oranları ile pozitif ve negatif beceri eksiklikleri ve cebirsel düşünme seviyelerine ait bulgulara yer verilmiştir. Çalışmanın amacına uygun olarak, öğrencilerin cebir öğrenme alanına yönelik başarı düzeyleri her bir soru için ilk, iki ve üç aşamada verilen doğru cevapların yüzde oranlarına göre belirlenmiştir. Kendine güven oranı ise öğrencilerin üçüncü aşamada ilk iki soruya verdikleri yanıttan ne kadar emin olduklarına göre toplam kendine güven (TKG) puanına ait yüzde oranı hesaplanarak belirlenmiştir.

Tablo 3

Cebir Öğrenme Alanı Ile Illgili Doğru Cevap Oranları

\begin{tabular}{ccccc}
\hline \multicolumn{5}{c}{ Doğru Cevap Oranı (\%) } \\
\hline Soru & ilk Aşama & iki Aşama & Üç Aşama & TKG (\%) \\
\hline 1 & 50 & 26 & 22 & 52 \\
2 & 46 & 25 & 16 & 45 \\
3 & 43 & 25 & 23 & 54 \\
4 & 45 & 22 & 18 & 57 \\
5 & 39 & 17 & 12 & 43 \\
6 & 69 & 32 & 30 & 65 \\
7 & 76 & 24 & 21 & 57 \\
8 & 49 & 21 & 12 & 42 \\
9 & 34 & 17 & 14 & 44 \\
10 & 63 & 32 & 24 & 52 \\
Ortalama & 51 & 24 & 19 & 51 \\
\hline
\end{tabular}

Tablo 3 incelendiğinde, ilk aşamadan son aşamaya doğru ilerledikçe doğru cevap oranlarının belirgin şekilde azaldığı dikkat çekmektedir. Buna göre, ilk aşamada \%51 doğru cevap oranı, iki aşamada \%24 ve üç aşamada \%19 olarak belirlenmiştir. Özellikle ölçme aracının ilk aşaması ile ikinci aşamasındaki doğru cevap oranları arasındaki farkın çok olması öğrencilerin hem doğru cevabı hem de cevaba ilişkin doğru çözümü yapmakta zorlandıklarını göstermektedir. Ancak iki aşamalı ve üç aşamalı olarak değerlendirme yapıldığında öğrencilerin \%5'lik bir kısmının iki aşamada doğru yanıt vermesine rağmen verdikleri yanıttan emin olmadıklarını göstermektedir. Dolaysıyla ilk üç aşamada gözlenen bu farklılıkların nedeni cebir öğrenme güçlüğü, kendine güven eksikliği ya da düşük cebir seviyesinden ileri geldiğini söylemek mümkündür. Nitekim öğrencilerin $\% 51$ 'inin verdikleri yanıttan emin olmalarına rağmen sadece \%24'ünün doğru yanıt vermesi bu görüşleri desteklemektedir. Diğer yandan öğrencilerin cebir öğrenme alanında sahip oldukları beceri eksikliklerinin değerlendirilmesi ikinci aşamada ele alınmıştır. Bu kapsamda veri setinden elde edilen puanlama kategorileri uyarınca pozitif ve negatif beceri eksiklikleri hesaplanmıştır. Öğrenci ilk aşamada doğru yanıt 
vermiş, sorunun çözümünü yanlış yapmış ancak emin veya oldukça eminse pozitif beceri eksikliği (PBE), öğrenci ilk aşamada yanlış yanıt vermiş, sorunun çözümüne ulaşmış ancak emin veya oldukça eminse negatif beceri eksikliği (NBE) şeklinde nitelendirilmiştir. İki ve üç aşama açısından pozitif ve negatif beceri eksikliklerine ait bilgilere Grafik 1'de yer verilmiştir.

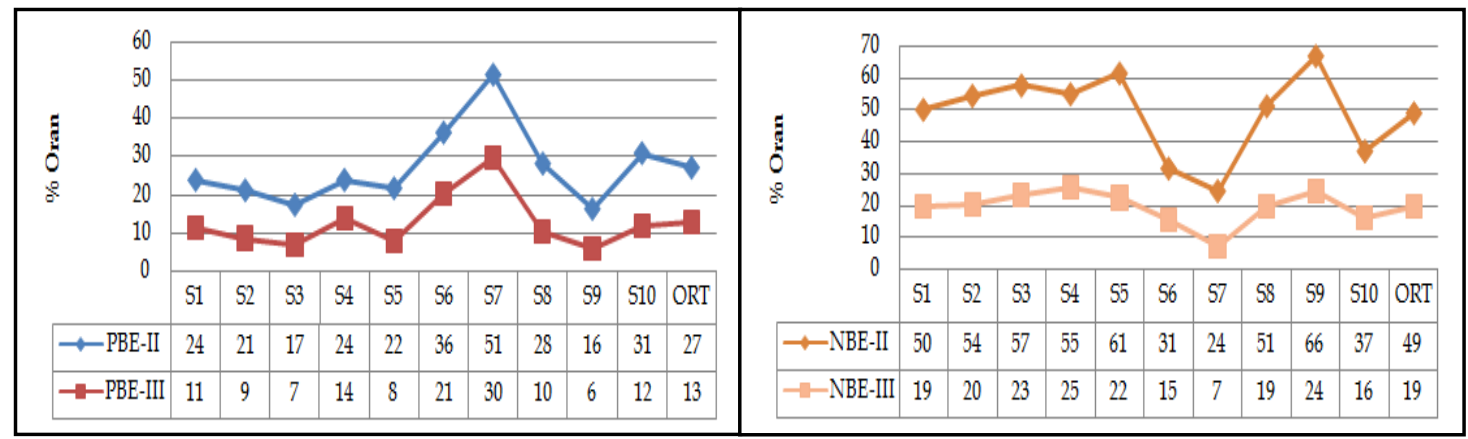

Grafik 1. Pozitif ve negatif beceri eksikliklerine ait değerler (S1: 1. Soru, S2: 2. Soru, S3...)

Hem pozitif hem de negatif beceri eksikliği ilk aşamada tespit edilemediğinden iki aşama ile üç aşama yönünden değerlendirme yapılmıştır. Grafik 1 incelendiğinde, aşama sayısına bağlı olarak beceri eksikliklerine ait dalgalanmalar dikkat çekmektedir. Örneğin, birinci soru için iki aşamada PBE görülen öğrenci oranı \%24 iken bu oran üç aşamalı olarak değerlendirildiğine \%11'e gerilemiştir. Benzer şekilde, NBE yönünden değerlendirildiğinde birinci soru için iki aşamada NBE görülen öğrenci oranı \%50 iken bu oran üç aşamalı olarak değerlendirildiğine \%19 olmuştur. Tüm sorular PBE ve NBE bağlamında değerlendirildiğinde ise benzer bulgular elde edildiği görülmektedir. Genel ortalama PBE için iki aşamada \%27, üç aşamada \%13 iken NBE için iki aşamada \%49, üç aşamada \%19 olarak hesaplanmıştır.

Bir öğrencinin çoktan seçmeli testlerde verdiği yanıtı gerçekten konu hakkında bilgi sahibi olduğu için mi yoksa şans eseri mi doğru yanıt verdiği konusunda oluşan tereddütler iki veya üç aşamalı olarak dizayn edilen testler ile daha ayrıntılı ve net bir şekilde belirlenebilmektedir (Peşman \& Eryılmaz, 2010). Dolaysıyla ölçme aracının üç aşaması birlikte değerlendirilerek öğrencilerin bilgi eksikliği ve şanslı tahmin oranları belirlenmiştir (bkz. Tablo 4). Bu bağlamda öğrencinin verdiği cevap için ilk aşama doğru, ikinci aşama yanlış; ilk aşama yanlış ikinci aşama doğru veya ilk iki aşama yanlış, son aşamada "Emin Değilim" veya "Kararsızım" ise bilgi eksikliği olarak değerlendirilmiştir. Diğer yandan öğrenci ilk iki aşamada doğru yanıt vermesine karşın üçüncü aşamada "Emin Değilim" ya da "Kararsızım" şeklinde yanıtta bulunmuşsa şanslı tahmin kategorisinde değerlendirilmiştir.

Tablo 4

Bilgi Eksikliği ve Şanslı Tahmin Oranları

\begin{tabular}{cccccccccccc}
\hline Soru & S1 & S2 & S3 & S4 & S5 & S6 & S7 & S8 & S9 & S10 & Ort. (\%) \\
\hline Bilgi eksikliği & 30 & 34 & 34 & 29 & 39 & 16 & 17 & 31 & 42 & 21 & 30 \\
Şanslı tahmin & 12 & 12 & 10 & 10 & 14 & 16 & 22 & 18 & 10 & 19 & 14 \\
\hline
\end{tabular}

Tablo 4 incelendiğinde, öğrencilerin ortalama \%30'unun cebir öğrenme alanında bilgi eksikliğine, \%14'ünün şanslı tahmine sahip olduğu görülmektedir. Öğrencilerin en fazla 9. soruda, en az ise 6. soruda bilgi eksiklerinin olduğu göze çarpmaktadır. Bunun yanı sıra şanslı tahmin oranı en yüksek 10. soru, en düşük 3., 4. ve 9. sorular olarak belirlenmiştir. 6. ve 7. sorular dışında tüm sorularda bilgi eksikliği oranları şanslı tahmin oranlarından daha fazla çıkmıştır. 6. soruda bilgi eksikliği ile şanslı tahmin oranları eşit iken 9. soru en çok cebir öğrenme güçlüğünün yaşandığı soru olmuştur. 
Bu aşamada, araştırmanın diğer alt problemlerinden biri olan ve açık uçlu soruların yer aldığı ikinci aşamaya göre öğrencilerin cebirsel düşünme düzeyleri hesaplanmıştır. Bu bağlamda, erkek ve kız öğrencilerin her bir soru için verdikleri yanıtlar 0-1-2-3-4 puan düzeylerine göre oranlandırılmıştır.

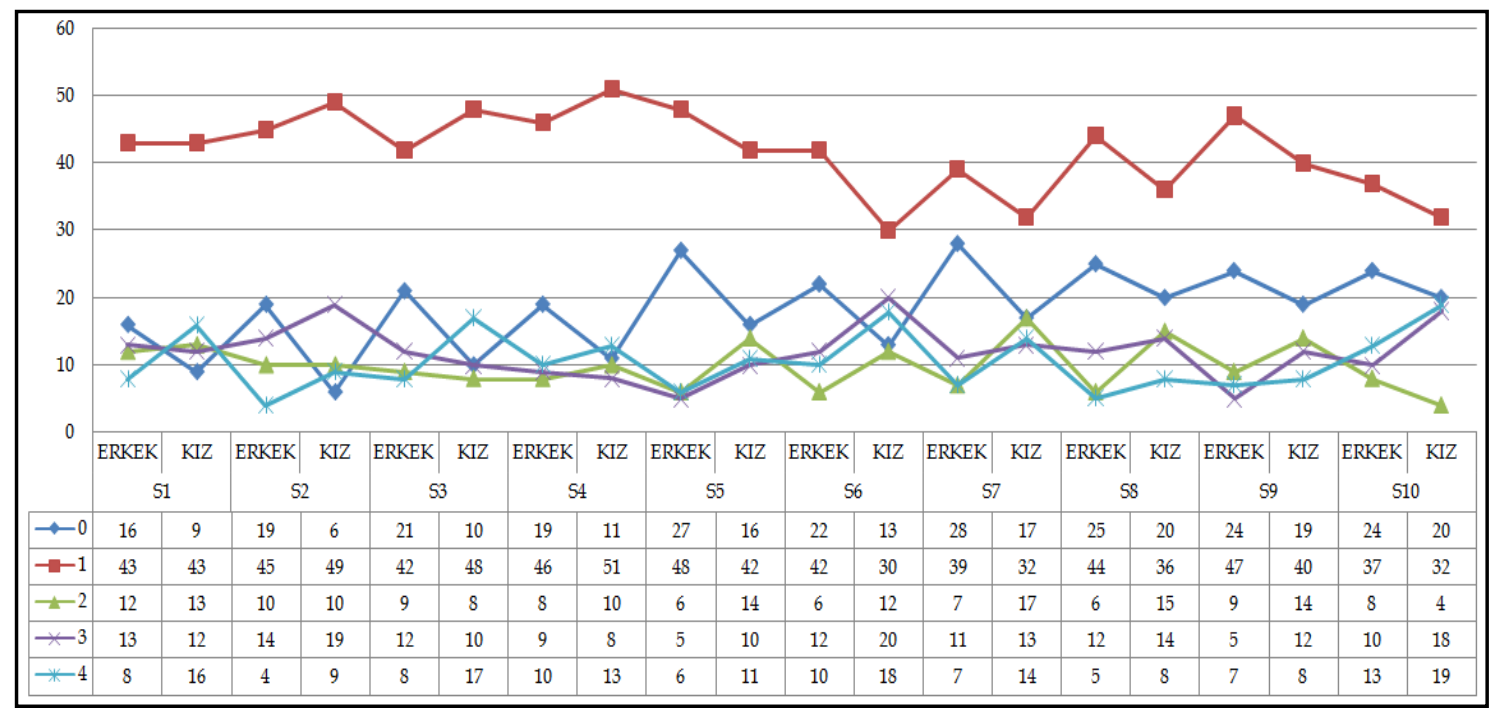

Grafik 2. Sorulara göre öğrencilerin cebirsel düşünme düzeylerine ait değerler

Grafik 2 incelendiğinde, hem kız hem de erkek öğrenciler için cebirsel düşünme düzeylerinin tüm sorular için düşük seviyeyi bantlarında sıklıkla yer aldığı görülmektedir. Cebirsel düşünmenin en düşük seviyesi olan 0 bandında birinci soru için toplam 25 (16 erkek, 9 kız), ikinci soru için 25 (19 erkek, 6 kız), üçüncü soru için 31 (21 erkek, 10 kız), dördüncü soru için 30 (19 erkek, 11 kız), beşinci soru için 43 (27 erkek, 16 kız), altıncı soru için 35 (22 erkek, 13 kız), yedinci soru için 45 ( 28 erkek, $17 \mathrm{kIz}$ ), sekizinci soru için 45 (25 erkek, 20 kız), dokuzuncu soru için 43 (24 erkek, 19 kız) ve onuncu soru için 44 (24 erkek, 20 kız) öğrencinin yer aldığı belirlenmiştir. Diğer yandan cebirsel düşünmenin en yüksek seviyesi olan 4 bandında birinci soru için toplam 24 (8 erkek, 16 kız), ikinci soru için 13 (4 erkek, 9 kız), üçüncü soru için 25 (8 erkek, 17 kız), dördüncü soru için 23 (10 erkek, 13 kız), beşinci soru için 17 (6 erkek, 11 kız), altıncı soru için 28 (10 erkek, $18 \mathrm{kız}$ ), yedinci soru için 21 (7 erkek, 14 kız), sekizinci soru için 13 ( 5 erkek, 8 kız), dokuzuncu soru için 15 ( 7 erkek, 8 kız) ve onuncu soru için 32 (13 erkek, 19 kız) öğrenci yer almaktadır. Elde edilen bulgular genel olarak irdelendiğinde, üst seviye bandında tüm sorularda kız öğrenci sayısı erkek öğrenci sayısından fazla iken en düşük seviye bandında erkek öğrenci sayısı kız öğrenci sayısından daha fazladır. Bu sonuçlara göre, kız öğrencilerinin erkek öğrencilere göre daha iyi performans sergilediklerini söylemek mümkündür. Öğrenci performanslarının çoğunlukla seviye 1 bandında yer alması ayrıca seviye 2 ile seviye 3 bandında yer alan öğrenci sayılarının birbirine yakın olması elde edilen diğer bulgular arasındadır. Öğrencilerin kısmen de olsa soruların cevabını açıklamaya çalıştığı seviye iki bandında erkek öğrenciler kızlara göre daha iyi bir ortalama puan sergilemiş olsa da cebirsel düşünmeleri düşük seviyede kalmıştır. Üçüncü seviye bandında ise yedi soruda kız öğrencilerin erkek öğrencilerden daha iyi bir performans sergiledikleri görülmektedir. Dördüncü seviye bandında ise kız öğrencilerin tamamı erkek öğrencilerden tüm sorularda daha iyi sonuç elde etmiştir. Sonuç olarak, yığılmanın daha çok seviye 1 bandında gerçekleşmiş olması ve seviye 4 bandına ilerledikçe öğrenci sayısının belirgin şekilde azalması öğrencilerin etkili bir cebirsel düşünme düzeyi performansından uzak olduğunu göstermektedir. 
Tablo 5

Öğrencilerin Cebirsel Düşünme Düzeylerine Ait Betimsel Değerler

\begin{tabular}{|c|c|c|c|c|c|}
\hline Sorular & Cinsiyet & Kişi Sayısı & Ortalama & Standart Sapma & Ortalama Standart Hata \\
\hline \multirow[t]{2}{*}{ Soru 1} & Erkek & 92 & 1.50 & 1.19 & .12 \\
\hline & $\mathrm{K} I \mathrm{Z}$ & 93 & 1.81 & 1.28 & .13 \\
\hline \multirow[t]{2}{*}{ Soru 2} & Erkek & 92 & 1.33 & 1.10 & .11 \\
\hline & Kız & 93 & 1.74 & 1.15 & .12 \\
\hline \multirow[t]{2}{*}{ Soru 3} & Erkek & 92 & 1.39 & 1.22 & .13 \\
\hline & KIZ & 93 & 1.74 & 1.31 & .14 \\
\hline \multirow[t]{2}{*}{ Soru 4} & Erkek & 92 & 1.40 & 1.23 & .13 \\
\hline & KIZ & 93 & 1.58 & 1.23 & .13 \\
\hline \multirow[t]{2}{*}{ Soru 5} & Erkek & 92 & 1.07 & 1.08 & .11 \\
\hline & Kız & 93 & 1.54 & 1.23 & .13 \\
\hline \multirow[t]{2}{*}{ Soru 6} & Erkek & 92 & 1.41 & 1.29 & .13 \\
\hline & $\mathrm{K} \mathrm{IZ}$ & 93 & 2.00 & 1.38 & .14 \\
\hline \multirow[t]{2}{*}{ Soru 7} & Erkek & 92 & 1.23 & 1.23 & .13 \\
\hline & Kız & 93 & 1.73 & 1.33 & .14 \\
\hline \multirow[t]{2}{*}{ Soru 8} & Erkek & 92 & 1.21 & 1.14 & .12 \\
\hline & KIZ & 93 & 1.50 & 1.23 & .13 \\
\hline \multirow[t]{2}{*}{ Soru 9} & Erkek & 92 & 1.17 & 1.12 & .12 \\
\hline & KIz & 93 & 1.46 & 1.20 & .12 \\
\hline \multirow[t]{2}{*}{ Soru 10} & Erkek & 92 & 1.47 & 1.36 & .14 \\
\hline & KIZ & 93 & 1.82 & 1.49 & .15 \\
\hline \multirow[t]{2}{*}{ Toplam } & Erkek & 92 & 1.32 & 1.04 & .11 \\
\hline & $\mathrm{K} \mathrm{IZ}$ & 93 & 1.70 & 1.02 & .11 \\
\hline Genel & Erkek+Kız & 185 & 15.09 & 10.48 & .77 \\
\hline
\end{tabular}

Tablo 5 incelendiğinde, kız öğrencilerin erkek öğrencilere göre tüm sorularda daha iyi sonuç elde ettiği görülmektedir. Ayrıca her bir soru için maksimum 4 puan alınabileceği dikkate alındığında hem erkek hem de kız öğrenciler orta düzeyin altında performans sergilemişlerdir. Her bir soruya göre erkek öğrencilerin ortalaması 1.32 iken kız öğrencilerin 1.70 olarak hesaplanmıştır. Ölçme aracının genel ortalaması ise 15.09 olarak bulunmuştur. 6 . sorudaki kız öğrencilere ait bulgular dışında cebirsel düşünme düzeyleri orta noktanın gerisinde kalmıştır. Bu sonuçlara göre, tüm soruların seviyelere göre sıklık tablosu aşağıda sunulmuştur.

Tablo 6

Tüm Sorulara Göre Öğrencilerin Cebirsel Düşünme Düzeyi Sıklık Tablosu

\begin{tabular}{cccccccc}
\hline Cinsiyet & Seviye 0 & Seviye 1 & Seviye 2 & Seviye 3 & Seviye 4 & Alt Seviye & Üst Seviye \\
\hline Erkek & 4 & 9 & 0 & 0 & 0 & 50 & 6 \\
Kız & 2 & 5 & 0 & 1 & 1 & 38 & 7 \\
Toplam & 6 & 14 & 0 & 1 & 0 & 88 & 13 \\
\hline
\end{tabular}

Tablo 6 incelendiğinde, 10 soruluk ölçme aracında toplam 6 öğrenci (4 erkek, 2 kız) soruların tamamında en düşük seviye bandında yer almıştır. Bu öğrenciler ölçme aracındaki tüm sorularda 0 puan almıştır. Ayrıca toplam 14 öğrenci ( 9 erkek, 5 kız) seviye bir bandında yer almıştır. Tüm sorular için seviye iki bandında hiçbir öğrencinin bulunmadığı ölçme aracında sadece $1 \mathrm{kız} \mathrm{öğrenci} \mathrm{hem} \mathrm{seviye} \mathrm{üç} \mathrm{hem} \mathrm{de} \mathrm{seviye} \mathrm{dört} \mathrm{bandında} \mathrm{yer} \mathrm{alııştır.} \mathrm{Tüm} \mathrm{bulgular} \mathrm{bir}$ arada değerlendirildiğinde, 88 öğrenci (50 erkek, 38 kız) alt seviye bandında [0-1-2], 13 öğrenci (6 erkek, 7 kız öğrenci) üst seviye bandında [3-4] yer alabilmiştir. 


\section{TARTIŞMA, SONUÇ VE ÖNERILER}

$\mathrm{Bu}$ araştırmada yedinci sınıf öğrencilerinin cebirsel düşünme düzeyleri ile cebir öğrenme alanındaki pozitif/negatif beceri eksiklikleri üç aşamada incelenmiştir. Araştırmadan elde edilen bulgular, öğrencilerin ilk aşamadaki doğru cevap yüzdesinin üç aşama olduğunda belirgin bir şekilde azaldığına işaret etmektedir. Özellikle açık uçlu soruların yer aldığı ikinci aşamaya geçildiğinde çoktan seçmeli testlere doğru yanıt veren öğrencilerin doğru çözüm yolunu açıklama veya gösterme konusunda yeterli başarıyı gösteremediği belirlenmiştir. Bunun dışında ikinci aşamada doğru çözüm yapan öğrencilerin \%5'lik gibi bir kısmı yanıtından emin olamamıştır. Ölçme aracının genelinde öğrencilerin kendine güven toplam puanı ise orta düzey seviyesinin (\%51) biraz üzerinde yer almıştır. Her ne kadar bu oran cebir gibi öğrenme güçlüğünün sıkça rastlanıldığı öğrenme alanı için olumlu bir sonuç gibi algılansa da üç aşamalık bir değerlendirmede tüm öğrencilerin ancak \%19'u arzulanan seviye ulaşabilmiştir. Elde edilen bu sonuç, Ersoy ve Erbaş (2005) tarafından bir grup Türk öğrencinin cebir başarılarının Kassel Projesi Cebir Testi ile belirlenmeye çalışıldığı çalışma bulguları ile örtüşmektedir. Özellikle eşitlik ve problemlerin yer aldığı sorularda öğrencilerin düşük başarı sergilemesi yürütülen çalışmanın sonuçlarını destekler niteliktedir. Ayrıca ölçme aracındaki problem çözme ağırlıklı cebir sorularında öğrencilerin zorlanması ve çözüm yolunu doğru bir şekilde belirleyememesi cebirde güçlük yaşadıklarının önemli bir kanıtı olduğunu söyleyebiliriz. Nitekim benzer bir sonuçta, Kaya ve diğer., (2016) tarafından 22 tanesi açık uçlu sorudan oluşan toplam 38 soruluk Cebirsel Muhakeme Değerlendirme Aracı'ndan elde edilmiştir. Buna göre, öğrenciler açık uçlu soruların yer aldığı tüm boyutlarda düşük başarı sergilemişlerdir. Diğer yandan aralarında Türkiye'nin yer aldığı ve toplamda 61 ülkenin katıldığı TIMMS 2015 raporunda cebir öğrenme alanının birçok ülke için sıkıntılara neden olduğuna işaret ederek genel matematik notu içinde cebir sorularında öğrencilerin oldukça düşük başarı sergiledikleri belirtilmiştir (TIMMS, 2016). Cebir öğrenmenin önemi ortada iken araştırmacılar öğrenciler için daha etkili bir cebir öğrenme ortamının nasıl olması gerektiği konusunda farklı yaklaşımlar önermektedir (Akkuş-Çıkla, 2004; Clement, 1999; Çağdaşer, 2008; Eski, 2011; Kar, Çiltaş \& Işık, 2011; Kaya, 2015; Moseley \& Brenner, 1997; Öner, 2009; Palabıyık, 2010; Tall \& Thomas, 1991; Witzel, 2005). Hiç şüphesiz bu girişimler öğrencilerin etkili cebir öğrenmelerine destek olabilir. Fakat her şeyden önce öğrencilerin cebire yönelik yeterlik düzeylerini artırmak için cebir konuları ile ilgili doğru, tam ve başarılı deneyimler kazanmalarına yardımcı ve destek olmak öncelikli hedef olmalıdır. Bunun için cebirsel içerikli konular işlenirken somuttan soyuta, kolaydan zora ve basitten karmaşığa öğretim ilkeleri doğru, etkili ve akıc bir şekilde planlanmalıdır. Nitekim bu yönde alanyazında da cebir öğretiminde somutlaştırma yaklaşımının önemi gibi benzer söylemlere sıkça rastlanılmaktadır (Milli Eğitim Bakanlığı [MEB], 2009; NCTM, 2000, 2006; Sfard, 1995).

Araştırmadan elde edilen diğer bir bulgu, öğrencilerin pozitif ve negatif beceri eksikliklerine yöneliktir. Öğrenci ilk aşamada doğru yanıt vermiş, sorunun çözümünde yetersiz kalmış ancak emin veya oldukça eminse pozitif beceri eksikliği, öğrenci ilk aşamada yanlış yanıt vermiş, sorunun çözümünde uygun çözüm yolu ve stratejisini geliştirmiş ancak emin veya oldukça eminse negatif beceri eksikliğine sahiptir. Elde edilen bulgulara göre, öğrencilerin değerlendirme aşamalarının artışına bağlı olarak hem pozitif hem de negatif beceri eksikliklerindeki değişim belirginleşmektedir. Bu durumun en önemli gerekçesi açık uçlu soruların yer aldığı ikinci aşamada öğrencilerin oldukça zorlanması olarak gösterilebilir. Nitekim PBE açısından değerlendirme yapıldığında, tüm sorularda öğrencilerin açık uçlu soruların çözümünü doğru şekilde yapamama oranları \%16-\%51 arasında değişim göstermektedir. Bu oranlar 185 kişilik bir çalışma grubu için dikkat çekici bir sonuçtur. Dolaysıyla iki aşama için öğrencilerin genelinde cebire yönelik olumlu bir performans sergilediklerini söylemek mümkün gözükmemektedir. Bu süreçte, öğrenciler çoktan seçmeli testi yanlış işaretlemesine rağmen, yanlış seçenek üzerinden ikinci aşamada doğru çözüme ulaşmıştır. Benzer şekilde, NBE 
açısından değerlenme yapıldığında, öğrencilerin çoğunluğunun çoktan seçmeli soruları yanlış cevaplandırmalarına rağmen açık uçlu soruların çözümüne etkili çözüm yolu belirleyebildikleri gözlenmiştir. Nitekim altıncı, yedinci ve onuncu soru dışındaki tüm sorularda öğrencilerin yarısından fazlası veya yakını her iki aşamada yanlış cevap vermiştir. Bu süreçte, öğrenciler negatif yönde bir beceri sergilemiş olmalarına rağmen yanlış cevaplarını savunmaktadırlar. Bunun yanı sıra öğrencilerin iki aşamada PBE ortalaması \%27, üç aşamada \%13 iken iki aşamada NBE ortalaması \%49, üç aşamada \%19 olarak hesaplanmıştır. Alanyazın incelendiğinde, Yenilmez ve Avcu (2009) tarafından 6 öğrenci ile yarı-yapılandırılmış görüşme tekniği ile yapılan çalışmada öğrencilerin açık uçlu sorulardan oluşan denklem kurma problemlerinde benzer güçlükler yaşadıkları belirlenmiştir. Özarslan (2010) tarafından 364 öğrenciye yönetilen 10 soruluk ölçme aracı ile yapılan çalışmada da öğrencilerin ilk soru dışındaki tüm soru maddelerinde ancak \%8.5 ile \%29.6 arasında başarı göstermeleri elde edilen bulguları desteklemektedir. Nitekim altıncı ve yedinci sınıflar düzeyindeki öğrenciler için sözel problemlere uygun denklem oluşturma, yorumlama, hesaplama ve cebirsel ifadeleri basitleştirme gibi işlemlerin oldukça zorlu bir sürece dönüşebildiği belirtilmektedir (Van Amerom, 2003).

Bu araştırmadan elde edilen diğer bir bulgu, öğrencilerin çoktan seçmeli testte doğru yanıtı verirken çözüme ulaşarak mı yoksa şans eseri mi cevapladığı noktasında elde edilen sonuçlardan oluşmaktadır. Bu bağlamda, öğrencinin verdiği cevap için ilk aşama doğru, ikinci aşama yanlış; ilk aşama yanlış ikinci aşama doğru veya ilk iki aşama yanlış ve son aşamada "Emin Değilim" veya "Kararsızım" ifadelerinden biri tercih edilmiş ise bilgi eksikliği olarak değerlendirilmiştir. Diğer yandan öğrenci ilk iki aşamada doğru yanıt vermesine karşın üçüncü aşamada "Emin Değilim" ya da "Kararsızım" şeklinde yanıtta bulunmuşsa şanslı tahmin (kendine güven eksikliği) kategorisinde değerlendirilmiştir. Elde edilen bulgulara göre, öğrencilerin ortalama \%30'unun bilgi eksikliği, \%14'ünün şanslı tahminde bulundukları belirlenmiştir. Bu sonuç, çoktan seçmeli sorularda öğrencilerin cevaba ulaşmalarının cebir öğrenme alanlarında yeterince bilgi sahibi olup olmadıkları noktasında alanyazına önemli ipuçları sunmaktadır. Çalışmanın en güçlü yönlerinden biri de cebir gibi soyut ifadelerin sıklıkla yer aldığı bir öğrenme alanı için açık uçlu soru türlerinin veya yazılı ifadelerin gerekliliğine vurgu yapmasıdır. Her ne kadar birçok başarı belirleme sınavlarında öğrencilere genellikle çoktan seçmeli sorular yöneltilse de öğrencilerin cebir becerilerinin daha iyi anlaşılması açısından açık uçlu sorulara sıkça yer verilmelidir. Yürütülen çalışmada olduğu gibi öğrencilerin çözümlerine duyuşsal yaklaşımla değerlendirmelerine imkân tanınması da faydalı olabilir.

Araştırmanın en önemli gerekçesini yansıtan bir diğer bulgu ise öğrencilerin çözüme yönelik cevaplarının değerlendirildiği bölümdür. Cinsiyete göre öğrencilerin cebirsel düşünme seviyelerinin belirlenmeye çalışıldığı bu bölümdeki bulgulara göre, gerek kız gerekse erkek öğrencilerin düşük seviye bandında sıklıkla yer aldığı görülmektedir. Örneğin birinci soru için 16 erkek, 9 kız öğrenci 0 düzeyinde, 43 erkek, 43 kız öğrenci 1 düzeyinde, 12 erkek, 13 kız öğrenci 2 düzeyinde, 13 erkek, 12 kı öğrenci 3 düzeyinde ve 8 erkek, 16 kı öğrenci ise 4 düzeyinde yer almaktadır. Tüm sorular birlikte değerlendirildiğinde, öğrencilerin çoğunlukla hiçbir yargıda bulunulmayan 0 bandı ile seçmiş olduğu çözüm yolunun niteliksiz olduğu 1 bandında yer almıştır. Bu sonuçlar, öğrencilerin cebirsel düşünme seviyelerinin oldukça düşük olduğunu göstermektedir. Bu durumun en önemli gerekçelerinden birisi de en üst seviye olan 4 bandında çok az öğrencinin yer alması olarak gösterilebilir. Nitekim birinci soru için 24, ikinci soru için 13, üçüncü soru için 25 , dördüncü soru için 23 , beşinci soru için 17 , altıncı soru için 28 , yedinci soru için 21 , sekizinci soru için 13 , dokuzuncu soru için 15 ve onuncu soru için toplamda 32 öğrenci en üst seviye bandında yer alabilmiştir. En yüksek değer olan onuncu soru için bile toplam öğrenci sayısının ancak \%17.3'ü bu seviyeye ulaşabilmiştir. Diğer yandan kız öğrencilerin ortalamasının, erkek öğrencilere göre daha iyi olduğu belirlenmiştir. Bu sonuca göre, kız 
öğrencilerin daha iyi performansa sahip olduğunu söyleyebiliriz. Ancak ölçme aracına ait genel ortalama (15.09) düşünüldüğünde tüm öğrencilerin performansı ölçme aracı orta noktasının [20 puan] oldukça gerisinde kalmıştır. Dolaysıyla tüm öğrencilerin cebir performansları arzu edilen seviyeden oldukça uzaktadır. Elde edilen bu bulgular, cebir konularında öğrencilerin oldukça zorlandığı ve iyi bir performans sergileyemedikleri söylemlerini desteklemektedir (Kaput \& Blanton, 2001; Dede \& Argün, 2003; Ersoy \& Erbaş, 2005; Kaya, 2015; NCTM, 2000; OECD, 2016; Özarslan, 2010; Soylu, 2008; TIMSS, 2016; Van Amerom, 2003). Çalışmadan elde edilen dikkat çekici bir diğer bulgu, kız öğrencilerin erkek öğrencilere göre dördüncü seviye bandında daha iyi performans sergilemiş olmalarıdır. Diğer yandan 2 kız ve 4 erkek öğrenci ise tüm sorularda yetersiz performans sergileyerek 0 bandında yer almıştır. Bunun dışında tüm sorular için seviye 2 bandında hiçbir öğrenci bulunmazken, seviye 3 bandında 1 kız öğrenci yer almaktadır. Öğrencilerin cevapları 0-1-2 alt seviye ve 3-4 üst seviye olarak nitelendirildiğinde 50 'si erkek, 38'i kız toplam 88 öğrenci alt seviye ve 6'sı erkek, 7'si kız olmak üzere toplam 13 öğrenci üst seviye bandında yer almaktadır. Çalışmadan elde edilen en çarpıcı bulgularından birisi de tüm sorulara doğru yanıt veren yalnızca bir öğrencinin olmasıdır. Bu bağlamda alanyazın irdelendiğinde, Erbaş, Çetinkaya ve Ersoy (2009) öğrencilerin doğrusal denklemlerin çözümünde karşılaşılan güçlükleri, Akgün (2007) değişken kavramı ve harfli ifadelerle işlem yapmadaki zorlukları, Soylu (2008) sözel problemlerde yaşanan sorunları, Rosnick (1981) denklem oluşturmadaki hataları incelemiş ve benzer bulgular elde etmiştir.

Çalışmadan elde edilen bulgular birlikte ele alındığında, yedinci sınıf öğrencilerinin cebirsel düşünme düzeylerinin alarm verdiğini söyleyebiliriz. Bu durumun en güçlü kanıtlarından birisi de her bir soru için öğrencilerin ölçek orta noktası 2 puanın altında sonuçlar elde etmesi gösterilebilir. Ayrıca maksimum 40 puan alınabilecek ölçme aracının tamamında 15.09 ortalama değeri ile \%37.7'lik bir performans sergilenmiş olması üzerinde düşünülmesi gereken diğer bir sonuçtur. Her ne kadar cebir konularının öğretimi ve öğrenimi konusunda birtakım sıkıntıların yaşanması bu durumun en güçlü gerekçesini oluştursa da erken yaşlardaki cebir öğretiminin önemli olduğu anlayışının yeterince anlaşılması gerekir. Yürütülen çalışmanın bulguları da, öğrencilerin cebir öğrenmelerinde çok ciddi problemlerin ve sıkıntıların olduğunu göstermektedir. Bu nedenle, özellikle ortaokul matematik dersi öğretmenlerinin öğrenci ilgi ve intiyaçlarına cevap verecek cebir öğrenme ortamlarının oluşturulması bilincine sahip olması son derece önemlidir. Diğer yandan hem öğretim programı hem de öğrenciler için hazırlanacak etkinlikler planlanırken cebirsel ifadelerin somutlaştırılmasına daha fazla özen gösterilmesi faydalı olabilir. Son olarak, araştırmanın bulguları ve yorumları doğrultusunda araştırmacılara bir takım öneriler sıralanmıştır:

$\checkmark$ Öğrencilerin cebirde yaşadıkları güçlüklerin temel nedenlerini belirlemeye yönelik öğretim programı dâhilinde boylamsal çalışmalara ağırlık verilebilir.

$\checkmark$ Farklı sınıf seviyelerinde benzer çalışmalar yürütülerek öğrencilerin cebirsel düşünme düzeylerindeki değişimler izlenebilir.

$\checkmark$ Geçmiş yıllarda düzenli aralıklarla yayınlanan uluslararası değerlendirme kuruluşlarının yayınladığı raporlarda yer alan cebir öğrenme alanına yönelik veriler ışığında daha derinlemesine karşılaştırmalar yapılabilir.

$\checkmark$ Nitel ve nicel içerikli karma yöntemler kullanılarak çalışma alanı genişletilebilir. 


\section{KAYNAKLAR}

Akgün, L. (2006). On algebra and the concept of variable. Journal of Qafqaz University, 17(1). Retrieved from http://journal.qu.edu.az/.

Akgün, L. (2007). Değişken kavramına ilişkin yeterlilikler ve değişken kavramının öğretimi. Yayınlanmamış doktora tezi, Atatürk Üniversitesi, Fen Bilimleri Enstitüsü, Erzurum.

Akkan, Y. (2009). Ilköğretim öğrencilerinin aritmetikten cebire geçiş süreçlerinin incelenmesi. Yayınlanmamış doktora tezi, Karadeniz Teknik Üniversitesi, Fen Bilimleri Enstitüsü, Trabzon.

Akkuş-Çıkla, O. (2004). Çoklu temsil temelli öğretimin yedinci sınıf öğrencilerinin cebir performansına, matematiğe karşı tutumuna ve temsil tercihlerine etkisi. Yayınlanmamış doktora tezi, Orta Doğu Teknik Üniversitesi, Fen Bilimleri Enstitüsü, Ankara.

Arslan, H. Ö., Ciğdemoğlu, C., \& Moseley, C. (2012). A three-tier diagnostic test to assess preservice teachers' misconceptions about global warming, greenhouse effect, ozone layer depletion, and acid rain. International Journal of Science Education, 34(11), 1667-1686.

Bağdat, O., \& Anapa-Saban, P. (2014). İlköğretim 8. sınıf öğrencilerinin cebirsel düşünme becerilerinin solo taksonomisi ile incelenmesi. The Journal of Academic Social Science Studies, 26, 473-496.

Baki, A., \& Bütüner, Ö. S. (2011). Cebirin tarihsel gelişimi. Turkish Journal of Computer and Mathematics Education, 2(3), 198-231.

Bills, L., Wilson, K., \& Ainley, J. (2005). Making links between arithmetic and algebraic thinking. Research in Mathematics Education, 7(1), 67-81.

Blanton, M., \& Kaput, J. (2003). Developing elementary teachers' algebra eyes and ears. Teaching Children Mathematics, 10(2), 70-77.

Cai, J. (2004). Developing algebraic thinking in the earlier grades: A case study of the Chinese elementary school curriculum. The Mathematics Educator, 8(1), 107-130.

Cai, J., \& Knuth, E. (2011). Early algebraization. New York: Springer.

Carpenter, T. P., \& Levi, L. (2000). Developing conceptions of algebraic reasoning in the primary grades. Research Report Madison, WI: National Center for Improving Student Learning and Achievement in Mathematics and Science. Retrieved from http://ncisla.wceruw.org/-publications/reports/RR-002.PDF.

Carraher, D. W., \& Schliemann, A. (2007). Early algebra and algebraic reasoning. In F. K. Lester (Ed.), Second Handbook of Research on Mathematics Teaching and Learning (Vol. 2, pp. 669-705). Reston: NCTM.

Clement, D. H. (1999). Concrete manipulatives, concrete ideas. Contemporary Issues in Early Childhood, 1(1), 45-60.

Cuoco, A., Goldenberg, P., \& Mark, J. (1996). Habits of mind: An organizing principle for mathematics curriculum. Journal of Mathematical Behavior, 15(4), 375-402.

Çağdaşer, B. T. (2008). Cebir öğrenme alanının yapılandırmacı yaklaşımla öğretiminin 6. sınıf öğrencilerinin cebirsel düşünme düzeyleri üzerindeki etkisi. Yayınlanmamış yüksek lisans tezi, Uludağ Üniversitesi, Sosyal Bilimler Enstitüsü, Bursa.

Dede, Y., \& Argün, Z. (2003). Cebir, öğrencilere niçin zor gelmektedir? Hacettepe Üniversitesi Eğitim Fakültesi Dergisi, 24(24), 180-185. 
Driscoll, M. (1999). Fostering algebraic thinking. A guide for teachers in grades 6 through 10. Portsmouth, NH: Heinemann.

Driscoll, M. D., Zawojewski, J., Humez, A., Nikula, J., Goldsmith, L., \& Hammerman, J. (2001). Fostering algebraic thinking toolkit. Portsmouth, $\mathrm{NH}$ : Heinemann.

Driscoll, M., \& Moyer, J. (2001). Using students' work as a lens on algebraic thinking. Mathematics Teaching in the Middle School, 6(5), 282-287.

Erbaş, A. K., Çetinkaya, B., \& Ersoy, Y. (2009). Öğrencilerin basit doğrusal denklemlerin çözümünde karşılaştıkları güçlükler ve kavram yanılgıları. Eğitim ve Bilim, 34(152), 44-59.

Ersoy, Y., \& Erbaş, K. (2005). Kassel projesi cebir testinde bir grup Türk öğrencinin genel başarısı ve öğrenme güçlükleri. Illköğretim Online, 4(1), 18-39.

Eski, M. (2011). Illköğretim 7. sınıflarda cebirsel ifadeler ve denklemlerin öğretiminde probleme dayalı öğrenmenin etkisi. Yayınlanmamış yüksek lisans tezi, Kastamonu Üniversitesi, Fen Bilimleri Enstitüsü, Kastamonu.

Irwin, K., \& Britt, M. (2005). The algebraic nature of students' numerical manipulation in the New Zealand Numeracy Project. Educational Studies in Mathematics 58(2), 169-188.

Kaput, J. J. (1999). Teaching and learning a new algebra with understanding. In E. Fennema \& T. Romberg (Eds.), Mathematics classrooms that promote understanding (pp. 133-155). Mahwah, NJ: Lawrence Erlbaum Associates.

Kaput, J. J., \& Blanton, M. (2001). Student achievement in algebraic thinking: A comparison of $3 r d$ graders performance on a 4 th grade assessment. In R. Speiser, C. Maher, \& C. Walter (Eds.), The Proceedings of the 23rd Annual Meeting of the North American Chapter of the International Group for the Psychology of Mathematics Education (Vol. 1, pp. 99107). Columbus, OH: ERIC.

Kaput, J. J. (2008). What is algebra? What is algebraic reasoning? In J. J. Kaput, D. W. Carraher \& M. L. Blanton (Eds.), Algebra in the early grades (pp. 235-272). New York: Lawrence Erlbaum Associates.

Kar, T., Çiltaş, A., \& Işık, A. (2011). Cebirdeki kavramlara yönelik öğrenme güçlükleri üzerine bir çalışma. Kastamonu Eğitim Dergisi, 19(3), 939-952.

Karasar, N. (2013). Bilimsel araştırma yöntemi (25. Baskı). Ankara: Nobel Yayın Dağıtım.

Kaya, D. (2015). Çoklu temsil temelli öğretimin öğrencilerin cebirsel muhakeme becerilerine, cebirsel düşünme düzeylerine ve matematiğe yönelik tutumlarına etkisi üzerine bir inceleme. Yayınlanmamış doktora tezi, Dokuz Eylül Üniversitesi, Eğitim Bilimler Enstitüsü, İzmir.

Kaya, D., Keşan, C., İzgiol, D., \& Erkuş, Y. (2016). Yedinci sınıf öğrencilerinin cebirsel muhakeme becerilerine yönelik başarı düzeyi. Türk Bilgisayar ve Matematik Eğitimi Dergisi, 7(1), 142-163.

Kieran, C., \& Chalouh, L. (1993). Prealgebra: The transition from arithmetic to algebra. In Douglas T. Owens (Ed.), Research ideas for the classroom: Middle grades mathematics (pp. 178-192). Reston, VA: National Council of Teachers of Mathematics.

Kieran, C. (1996). The changing face of school algebra. In C. Alsina, J. Alvarez, B. Hodgson, C. Laborde, \& A. Pérez (Eds.), 8th International Congress on Mathematical Education: Selected lectures (pp. 271-290). Sevilla, Spain: S. A. E. M. Thales. 
Lawrence, A., \& Hennessy, C. (2002). Lessons for Algebraic Thinking (Grades 6-8). Math Solutions Publications: Sausalito, CA.

Lew, H. C. (2004). Developing algebraic thinking in early grades: Case study of Korean elementary school mathematics. The Mathematics Educator, 8(1), 88-106.

Marzano, R. J. (2000). Transforming classroom grading. Alexandria, VA: Association for Supervision and Curriculum Development.

Mason, J. (1996). Expressing generality and roots of algebra. In N. Bednarz, C. Kieran \& L. Lee (Eds.), Approaches to algebra (pp. 65-86). Dordrecht: Kluwer.

Mason, J., Graham, A., \& Johnston-Wilder, S. (2005). Developing thinking in algebra. London, UK: Paul Chapman Publishing.

Milli Eğitim Bakanlığı (MEB) (2009). Ilköğretim matematik dersi 6-8. sınıflar öğretim programı ve kılavuzu. Ankara: MEB.

Moseley, B., \& Brenner, M. E. (1997). Using multiple representations for conceptual change in pre-algebra: A comparison of variable usage with graphic and text based problems (pp. 29-30). Washington DC: Office of Educational Research and Improvement.

Moses, B. (1995). Algebra the new civil right. In C. Lacampagne, W. Blair, \& J. Kaput (Eds.), The algebra colloquium (Vol. 2, pp. 53-67). Washington, DC: US Department of Education.

National Council of Teachers of Mathematics (NCTM) (2000). Principles and standards for school mathematics. Reston, VA: Author. Retrieved from http://www.nctm.org/.

National Council of Teachers of Mathematics (NCTM) (2006). Curriculum focal points for prekindergarten through grade 8 mathematics: $A$ quest for coherence. Reston, VA: Author. Retrieved from http://www.nctm.org/.

Organisation for Economic Co-operation and Development (OECD) (2016). PISA 2015 results in focus. OECD, Paris. Retrieved from http://www.oecd.org/pisa/.

Öner, A. T. (2009). illköğretim 7. sınıf cebir öğretiminde teknoloji destekli öğretimin öğrencilerin erişi düzeyine, tutumlarına ve kalıcılığa etkisi. Yayınlanmamış yüksek lisans tezi, Dokuz Eylül Üniversitesi, Eğitim Bilimler Enstitüsü, İzmir.

Özarslan, P. (2010). Illköğretim 7. sını öğrencilerinin cebirsel sözel problemleri denklem kurma yoluyla çözme becerilerinin incelenmesi. Yayınlanmamış yüksek lisans tezi, Çukurova Üniversitesi, Sosyal Bilimleri Enstitüsü, Adana.

Palabıyık, U. (2010). Örüntü temelli cebir öğretiminin öğrencilerin cebirsel düşünme becerileri ve matematiğe yönelik tutumlarına etkisi. Yayınlanmamış yüksek lisans tezi, Hacettepe Üniversitesi, Sosyal Bilimler Enstitüsü, Ankara.

Peled, I., \& Carraher, D. W. (2004). Extending additive structures: The symbiosis between signed numbers and an algebrafied curriculum. To appear in J. Kaput \& D. Carraher (Eds.), Studies of Early Algebra.

Peşman, H., \& Eryılmaz, A. (2010). Development of a three-tier test to assess misconceptions about simple electric circuits. The Journal of Educational Research, 103(3), 208-222.

Radford, L. (2014). The progressive development of early embodied algebraic thinking. Math Ed Res J, 26(2), 257-277.

Rosnick, P. (1981). Some misconceptions concerning the concept of variable. Mathematics Teacher, 74(9), 418-420. 
Schliemann A. D., Carraher D. W., \& Brizuela B. M. (2007). Bringing out the algebraic character of arithmetic: From children's ideas to classroom practice. Hillsdale, NJ: Erlbaum.

Sfard, A. (1995). The development of algebra: Confronting historical and psychological perspectives. Journal of Mathematical Behavior, 14(1), 15-39.

Shternberg, B., \& Yerushalmy, M. (2003). Models of functions and models of situations: On the design of modeling-based learning environments. In R. Lesh \& H. M. Doerr (Eds.), Beyond constructivism: Models and modeling perspectives on mathematics teaching, learning, and problem solving (pp. 479-498). Mahwah, NJ: Lawrence Erlbaum Associates, Inc.

Slavit, D. (1999). The role of operation sense in transitions from arithmetic to algebra thought. Educational Studies in Mathematics, 37(3), 251-274.

Soylu, Y. (2008). 7. sınıf öğrencilerinin cebirsel ifadeleri ve harf sembollerini (değişkenleri) yorumlamaları ve bu yorumlamada yapılan hatalar. Selçuk Üniversitesi Ahmet Keleşoğlu Eğitim Fakültesi Dergisi, 25, 237-248.

Stacey, K., \& MacGregor, M. (1999). Learning the algebraic method of solving problems. The Journal of Mathematical Behavior, 18(2), 149-167.

Swafford, J. O., \& Langrall, C. W. (2000). Grade 6 students' preinstructional use of equations to describe and represent problem situations. Journal for Research in Mathematics Education, 31(1), 81-112.

Tabach, M., \& Friedlander, A. (2003). The role of context in learning beginning algebra. Proceedings of the Third Conference of the European Society for Research in Mathematics Education (28 February-3 March). Bellaria, Italia.

Tall, D., \& Thomas, M. (1991). Encouraging versatile thinking in algebra using the computer. Publisher in Educational Studies in Mathematics, 22, 125-147.

Tekin, H. (2016). Eğitimde ölçme ve değerlendirme (25. Baskı). Ankara: Yargı Yayınevi.

Trends in International Mathematics and Science Study (TIMSS) (2016). Highlights from TIMSS and TIMSS advanced 2015. Retrieved from https://nces.ed.gov/timss/timss2015/ .

Van Amerom, B. (2002). Reinvention of early algebra: Developmental research on the transition from arithmetic to algebra. Unpublished doctoral dissertation, University of Utrecht, Netherlands.

Van Amerom, B. (2003). Focusing on informal strategies when linking arithmetic to early algebra. Educational Studies in Mathematics, 54(1), 63-75.

Witzel, B. S. (2005). Using CRA to teach algebra to students with math difficulties in inclusive settings. Learning Disabilities: A Contemporary Journal 3(2), 49-60.

Wuttiprom, S., Sharma, M. D., Johnston, I. D., Chitaree, R., \& Soankwan, C. (2009). Development and use of a conceptual survey in introductory quantum physics. International Journal of Science Education, 31(5), 631-654.

Yenilmez, K., \& Avcu, T. (2009). Altıncı sınıf öğrencilerinin cebir öğrenme alanındaki başarı düzeyleri. Ahi Evran Üniversitesi Eğitim Fakültesi Dergisi, 10(2), 37-45. 


\section{SUMMARY}

Algebra is a learning field that depicts the abstractness of mathematics and opens the door ajar for abstract thinking due to its nature. Due to this characteristic, it not only opens the door to enable students to reach logical conclusions and think in an abstract manner, but also undertakes the duty of being a bridge and language between the elements of other sciences (Stacey \& MacGregor, 1999). Such an intense knowledge and skill accumulation in algebraic field brings with it the need for algebraic thinking. Algebraic thinking is a type of mental activity, and represents the establishment of connections between algebraic relations by making sense of symbols; depict the concrete-half-concrete and abstract concepts that exist in algebraic relations and making conclusions by reasoning (Kaya, 2015). No doubt, the need for algebra is inevitable not only for mathematics but also for many other disciplines. The multiple characteristics of algebra and its under taking critical roles in many different functions prepares the medium in which students can use their algebraic thinking skills in the most accurate and in the most productive manner. For this reason, especially in today's societies in which changes and developments are experienced in a fast manner, monitoring the levels of students in algebraic thinking is important. In this context, investigating the algebraic thinking levels of students appear before us as a field worth dealing with to prepare a source for national and international institutions and research, because it is extremely important to determine the changes in the algebraic thinking levels of students depending on the increase in the quality of education and training activities. In the light of the above mentioned data, the present study contributes to the understanding of several studies in the literature by investigating the (i) algebraic thinking levels of seventh grade students according to gender, and (ii) examining positive and negative skill deficiencies in algebraic field.

The literature review method was used in the study since the skill deficiencies of seventh graders in algebraic thinking and in algebraic learning field was investigated. The study group consisted of 185 students 93 of whom were female (50.3\%) and 92 of whom were male $(49.7 \%)$ studying at a state secondary school in 2016-2017 academic year. As the data collection tool, the "Algebraic Thinking Level Determination Tool" consisting of 10 questions prepared by considering the acquisitions mentioned in the course books and in the curriculum in secondary school mathematics books and the studies in the literature. The Cronbach alpha reliability coefficient of the scale consisting of 10 questions was calculated as .89 . In addition, the $27 \%$ item difficulty in the lower and upper group of the ATLDT was determined as .42-.73; the distinctiveness level was .46-.80; the item difficulty levels for the first two stages were .30-.45, the distinctiveness level was .38-.86; and the item difficulty level for the third stage was .20-.43, and the distinctiveness level was .38-.86. The measuring reliability values of the tool for the first two stages and the third stage were calculated as .69, .92 and .90. In addition, it was determined that there was a positive and significant relation between the two stage points and self-confidence total points $(N=185, r=.45, p<0.001)$, and those that had high points in two stages also had high points in selfconfidence field. For each question, it was determined that the correlation coefficient between the stage three point and total points was .54, and all the items in the measuring tool were bigger than .20 and are within acceptable values. In analyzing the dataset, the SPSS 22.0 program was used. "True" was encoded with " 1 " and "wrong" was encoded with " 0 " if the first stage in which multiple choice questions were placed was correct. In the second stage, the graded point's scale of Marzano (2000) was made use of. In the third stage, " 1 " was encoded for "I am sure" or "I am extremely sure" statements; and " 0 " for "I am indecisive" or "I am not sure". If the first two stages were true, sure or extremely sure in the answer of the student, it was accepted as "Advanced Algebraic Level". If the first stage was true for the answer of the student and the second stage was wrong, but the third stage was sure or extremely sure, it was accepted as "positive skill deficiency". If the first stage was wrong, the second stage true, and the last stage was sure or extremely sure; it was accepted as "negative skill deficiency". If the answer of the student was wrong for the first two stages but sure or extremely sure for the last stage, it was accepted as "low algebraic level"; and if it was true for the first two stages, but the last stage was not sure or indecisive, it was accepted as "lucky guess". On the other hand, if the first stage was wrong in the answer of the student, the second stage was true, and the third stage was not sure or indecisive, "unsure positive skill", is the first stage was true, the second stage was wrong, and the third stage was not sure or indecisive, it was accepted as "unsure negative skill". If the first two stages were wrong, and the last stage was not sure or indecisive, it was accepted as "algebraic learning difficulty". 
It is interesting that as the rate of the true answers of the students decrease in a clear manner as we move towards the last stage from the first stage. In this context, the true answer rate was determined as $51 \%$ in the first stage, $24 \%$ in the second stage, and $19 \%$ in the third stage. The general average was calculated as $27 \%$ in two stages and $13 \%$ in three stages for positive skill deficiency, it was calculated as $49 \%$ in two stages and $19 \%$ in three stages for negative skill deficiency. It was observed that $30 \%$ of the students in average had skill deficiency in algebraic learning field, and $15 \%$ had lucky guess. While the number of the female students was more than that of the male students in all questions in upper-level band; the number of male students is more than that of the female students in lower-level band. The student performances being mostly in level 1 and the number of the stunts in level 2 and 3 being close to each other are among the other findings of the study. Although in the level two band in which students tried to answer the questions -although partly- male students showed a better performance than the female students, it is understood that their algebraic levels are low. In the third level band, it was observed that female students had better performance than male students in seven questions. In the fourth level band, on the other hand, all female students had better results when compared with the male students. According to each question, while the average of male students was 1.32, the average of female students was calculated as 1.70. The general average of the measuring tool was found to be 15.09. When all the findings were analyzed together, 88 students were in the lower level band, and 13 students were in the upper level band.

When the findings obtained in the study were analyzed together, we may claim that the algebraic thinking levels of seventh grade students give alarm. One of the strongest evidence of this situation is the students' receiving points that were below 2, which is the average pint of the scale, for each question. In addition, the $37.7 \%$ performance in the scale with an average value of 15.09 in the whole of the scale from which the highest possible point is 40 is an interesting result requiring considerations. No matter the difficulties in teaching and learning algebraic topics are given as the strongest justification for this situation, it must be understood well that the algebraic education is extremely important in early ages. The findings of this study show that students have very serious problems in learning algebra. In this context, especially mathematics teachers must have the conscious of forming the environment for students to facilitate learning algebra in terms of their interests and needs, which is an extremely important issue. On the other hand, it might be useful to care more about the concretization of algebraic expressions when planning activities for curriculum and students. 